\begin{tabular}{|c|}
\hline Journal of Political Science \\
(A Peer-Reviewed, Open Access International Journal) \\
ISSN 2362-1273 (Print); ISSN 2773-8132 (Online) \\
Volume 21, February 2021, pp. 1-8 \\
https//: www.ejournal of pncampus.edu.np/journals/ips/ \\
\hline
\end{tabular}

\title{
Federal Democratic Republic of Nepal: An Assessment of the Rule of Law
}

\author{
Than Bahadur Chhetri \\ Department of Political Science \\ Prithvi Narayan Campus, Pokhara
}

Corresponding Author: Than Bahadur Chhetri, Email: than.chhetri@prnc.tu.edu.np DOI: https://doi.org/10.3126/jps.v21i0.35258

Received 2 December, 2020, Reviewed 15 December 2020, Published 1 February 2021

\begin{abstract}
The Rule of law, a set of principles of governance, apply to all individuals, organizations and the government itself. Democracy is a political system governed by the rule of law. No rule of law means no democratic future. This paper-aims to assess the state of the rule of law under the new political setup, taking the rule of law as dependent variable and fundamental rights, corruption, open parliament and independent judiciary as independent variables. To measure the rule of law, necessary information was collected from printed and online sources. A federal democratic republic can grow healthy only when there exists the rule of law and efficient state institutions. The fundamental problems in strengthening the rule of law obstructed by the tendency of personalization and frequent intervention in state institutions, high level of corruption at policy level, poor legislative bill formulation, the controversial appointing process of the judges and the political dominations. The acceptance of international norms to address the justice and to promote human rights, adhering to the principle of inclusion and equality, maintaining transparency rule in the appointment in various constitutional bodies and keeping out of executive influence to maintain impartial and independent institutions can help in strengthening the rule of law.
\end{abstract}

Keywords: Corruption, democracy, equality, judiciary, inclusion

\section{Introduction}

A federal democracy is a form of democratic political institution (at national, provincial and local levels based on the written constitution with clear jurisdictional authority in each level of government) governed by the rule of law, not by the rule of the rulers. Even the laws passed by the government will not be effectively implemented in the absence of the rule of law. Judiciary as an independent institution can play an effective role in the implementation of the rule of law, reducing corruption, combating against poverty and disease, protecting 


\section{Federal Democratic Republic of Nepal}

people from injustices as well as stability of democracy (Kosmehl, 2020). Democracy means creating a democratic society and building democratic institutions. It starts with the end of the autocratic regime. "Living under democratic institutions makes people much happier than living under authoritarian institutions" (Inglehart, 2009, p. 97) because it 'ensures political rights and civil liberties citizen from the state' (Heyhood, 2004)

The Constitution of Nepal (2015), promulgated by the constituent assembly, accepted the country as a federal democratic republican state and divided the state power into federal, provincial and local governments. The constitution (recently observed the fifth constitutional day) imagines the rule of law, guarantee of rights, participatory democracy and a system of check and balance to prevent abuse of authority and good governance that are necessary for democracy. Proper functioning of democratic republic system depends on independent and efficient legal systems (Council of Europe, 2016). The rule of law is the most vivacious postulate prerequisite for proper functioning of federal republic system under a principle of governance in which all institutions, persons, entities, public and private including the state are accountable to the laws that are publicly promulgated and equally enforced. There is a comprehensive recognition that transformation to federalism will have resilient effects on the quality of the country's governance. However, there remains pervasive apprehension that those in decision-making positions in government under a federal structure will evade their responsibility and decide for superficial adjustments rather than drastic fundamental change.

The role of judiciary will be a key in compelling statutory values in government beginning with the rule of law and entrée to justice - and causative to the success of the transformation to federal system of governance. Under a federal structure, the rule of law stresses public justification for the workout of public power supported by the judicial branch as the expression of its own authority, one to which public actors and citizens must learn to follow. However, the dejection and relegation of the judiciary over many years is part of a disreputable story of complicity by political parties across the continuum to deteriorate, co-opt and manipulate state institutions that dissuade impunity and restrain deviousness. Further, there is no guarantee that the elected representatives and appointed officials will abide by the rules as everyone else. Absence of the rule of law and misuse of the constitution will create a threat to federalism. Given this predicament, this paper endeavors to assess the state of the rule of law in Nepal under the new political federal setup.

\section{Literature Review}

The rule of law denotes a set of rules, procedures and principles of governance that apply to all individuals and organizations, including the government itself with international rights and standards (The United Nations, 2020). It is the heart of building and practicing democracy based on four principles: 'accountability, just laws, open government and accessible Justice' (WJP Rule of Law Index, 2020). Scholars and international agencies have adopted different approaches to measure the rule of law. For instance, the USAID (2008) uses 'order and security, legitimacy, checks and balances, fairness and effective application' as indicators to measure the rule of law. The WJP Rule of Law Index (2020) assesses the adherence of the rule of law in 128 countries through nine factors. They include Constraints on Government Powers, absence of corruption, open government, fundamental rights, order and security, regulatory enforcement, civil justice, and criminal justice. 


\section{Federal Democratic Republic of Nepal}

The Worldwide Governance Indicators (WGI, 2020) evaluates the quality of governance covering over 200 countries, uses six indicators in the rule of law. It takes the rule of law under executive accountability and confidence in the judicial system, and trust in judiciary to measure the rule of law. Human Freedom Index (2019) measures the state of civil and economic freedom using 76 indicators in the world and uses 'procedural justice', 'civil justice', and 'criminal justice' as the categories of the rule of law. Democracy demands more people's participation in the decision making process. People around the world are demanding more open government and open parliament, especially citizen participation in policy making (WJP, 2015). On the basis of the above discussion, this paper uses fundamental rights, corruption, open government and open parliament and judiciary as an independent variables to measures the state of the rule of law in Nepal.

\section{Data and Method}

Recently, Nepal observed its fifth constitution day. But there exist certain problems in achieving fundamental rights, good governance, citizen participation in legislative bill, and citizen's trust in justice. This article esteems fundamental rights, corruption, open parliament and independent judiciary as independent measuring variables to explain the state of the rule of law. As this is study is based on the past studies, required data have been collected from different secondary sources, both national and international research works that covers the period between 2018 and 2020 .

\section{Results and Discussion}

\section{Fundamental rights}

Fundamental rights are those group rights derived from the constitution, which are important for personal development of every individual. The new constitution of Nepal accepts international standards in fundamental rights. In terms of its practice, women are still far away to realize equal rights, especially in citizenship, marriage and social justice (UN, Asia and the Pacific, 2020) as well as in participation in decision making. The charter ensures 33 percent women in all sectors. Except legal and constitutional binding, their number in the federal and provincial cabinet as well as in the party is minimal. Likewise, political leaders hardly practice the inclusion policy inside and outside the organization.

According to Informal Sector Service Centre (INSEC, 2020), data on 'sexual and online violence' show that it is on the increasing trend every year. The existing law is inadequate to address 'online gender-based violence'. The law of the country prohibits reconciliation between victims and perpetrators, but remains common in practices (TRIAL International, 2020). Since long, many children of single mothers deprived of their fundamental rights such as lack of new citizenship law. The Dalit community across the country remains deprived of fundamental rights and discrimination (Pant, 2020). The Minority Rights Group International (2020) reports that Dalits with disabilities are one of the most excluded groups in Nepal. The government has not taken any concrete step to ensure their rights. Similarly, the Lesbian Bisexual Transgender Intersex (LBTI) is unable to practice their rights to equality. In spite of progress in laws and policy in the education sector, children with disabilities are out of the school. 


\section{Federal Democratic Republic of Nepal}

The law of the country states that torture of any form is a crime; the national media and international community report the number of death person in the custody is a rising trend. There has been no major change in police abuse. The police are failing to uphold the lives and human rights of the prisoners and give compensation to the families of victims of alleged extrajudicial killings and custodian deaths. For example, without proper warning, the Chitwan National Park government authorities set two houses ablaze and destroyed eight others with the use of elephants. There has been no successful action from the government against the prosecutors. Similarly, survivors of natural disasters do not get adequate relief form the government, such as shelter (World Report, 2020).

The government and the warlords signed a peace agreement nearly 14 years ago, but there has been no effort in addressing concerns of the victims of human rights violation during the conflict periods. Like the previous governments, the present one is showing less interest in resolving cases against those accused of conflict-era violations at different courts in spite of the court's order. There has been no positive development on the government side to address sexual violence by the security forces and Maoist combatants during the conflict era. Recently, in spite of wide criticism from all sides, the murder convicted leader Balkrishna Dhungel received presidential pardon from serving the rest of his jail sentence, who was serving a jail sentence after being found guilty. It is against the spirit of the court's order and the peace agreement. Receiving justice remains a distant dream for Ganga Maya Adhikari (INSEC, 2020). Some international agencies have been raising concerns over delays in concluding the transitional justice process.

\section{Corruption}

The South Asian countries, in the words of Gunnar Myrdal in his famous book Asian Drama, consist of various types of evils in comparison to Europe, terming it the 'soft state'. In such as society, there are various types of "social indiscipline which manifest themselves by deficiencies in legislation and, in particular, law observance and enforcement, a widespread disobedience by public officials and, often, their collusion with powerful persons and groups" (Myrdal,1970, p. 208).

Nepal, as a part of South Asia, possesses the features of dishonest and unethical behavior among the public officials and elected leaders for private gains. Various reports state that corruption in Nepal has "heightened all areas of state affairs involving top public position holder political leaders and business persons" (Panta, 2020; p. 130). Grand corruptions are occurring at policy level, mega projects and licensing, aircraft purchase, leasing out of government land and equipment purchase. At petty level, due to immoral behavior in service providers, corruption is seen in administrative level (Panta, 2020). The survey of the Commission for Investigation of Abuse of Authority's study on the topic "Corruption and Good-Governance in Nepal-2075," reports that local governments are the most corrupt institutions in the country. Globally, Nepal ranks 113th out of 180 countries. Transparency alone is insufficient in improving governance. The Transparency Annual Report (2020) survey shows that there has been no improvement in corruption matters. The Government of Nepal is intolerant against corruption.

Constitutional bodies are considered as independent in a democratic society always demand competent and impartial persons. They are unable to function as independently due to 


\section{Federal Democratic Republic of Nepal}

personalization and frequent intervention by the ruling political elites and lack of need human resources, share constitutional bodies and public institutions on the basis of 'bhagbanda', as their ancestral property, which is against the spirit of democracy. Such culture is adding a fertile ground for more corruption.

The Abuse of Authority has been remained infamy due to ignoring and suspending the grand corruption investigation, giving more attention on petty corruption. The commission remains unsuccessful to catch big fishes. People and the media are raising questions over the relevance of the commission. The politicians are also accused of protecting several corrupt government officials, who are accused of channeling the funds. Sometimes corrupt officials act as a bridge between the politicians and contractors of bigger projects and owners of big corporate houses.

\section{Open Government and Open Parliament}

People are the source of power in a democratic society. An active participation of civil society organizations and media in the form of input in pre-legislative and post-legislative policy making stages fosters in creating better laws, government accountable and promotes legitimacy of the democratic regime and checks irregularity of the executive. Hence, democratic government "must provide continue opportunity for the people to have a say in how the laws are made and implemented" (Sodaro \& Brown, 2001, p. 78).

In the context of Nepal, political leaders lack a culture of abiding constitutional values. The subjects' committee in the parliament still has not developed culture of citizen participation or taking consultation and suggestions from the stakeholders while drafting bills. The constituent assembly secretariat had received constructive feedback from individuals and organizations both within and outside the country on a preliminary draft of the constitution. But the leaders of the major political parties in the constituent assembly amended the constituent assembly rules and adopted first track process to promulgate the new statue without accommodating collected feedback. It contributed a violent movement against the constitution (International Justice Resource Center, 2015). After the promulgation of the new constitution, in the name of meeting constitutional deadline, both the upper and lower house hurriedly passed 16 laws related to the constitution rights without a proper discussion in the parliament.

The Oli led government introduced several controversial bills in the parliament (Medical Education Bill to the Media Council Bill and the Guthi Bill, University Bill) without taking feedback from the stakeholders. Coming under the pressure of citizens, the government withdrew some of the bills. New legislative bills in Nepal are prepared by a small group of people and sent to Bidhayan Samiti' Hereafter, it goes to parliament without pre-discussion and justification of the proposed laws. Neither the legislators of the ruling party nor the opposition actively participate in making law in the parliament. The provincial governments follow the same method, copy and paste of law is practicing at local levels. It seems that laws are made and passed from the parliament to please the certain group of people. Such practices neither solve the problems nor accommodate the interest of the people. The Freedom Forum (2020) states that the government of Nepal maintains weak transparency and oversight during the budget process as well as it provides few opportunities for the civil 


\section{Federal Democratic Republic of Nepal}

society and people to participate in shaping budget policies or monitoring their implementation as well as it lacks an Independent Fiscal Institution (IFI) in the country.

\section{Judiciary}

If there is no rule of law, there is no democratic society. Hence, a democratic government needs autonomy, transparency and independent judiciary in preventing violations of fundamental rights and protecting and promoting the rights guaranteed by the national and international laws and conventions. Judiciary redresses for violations of fundamental rights and human rights and protects the notion of the rule of law. The International Commission of Jurists (ICJ, 2020) has also identified many weaknesses in practicing judicial independence, a cornerstone of the rule of law. The disputes over the appointment of judges always become headlines in media. Due to 'political influence and manipulation' public faith over the impartiality and independent judiciary is low.

A few months ago, judges were appointed to the vacant position at different layers of court. The Nepal Bar Association (NBA) raised questions about their work competence and qualification of some of those appointed judges. The Judicial Council, known as an independent body, recommended the appointment of five judges for the Supreme Court and 18 judges for the High Court on the basis of loyalty to a particular party and family relationship (INSEC, 2020) without caring the inclusion provision of the constitution. It denotes that the judiciary to is not abiding by the constitutional principles.

The 'rule of law' is a set of 'principles or ideals' that helps in establishing an orderly and just society. Nepal is on the way of institutionalizing a federal democratic republic since 2015. It needs effective implementation of the rule of law to materialize the ideal dream, that is, democracy. Despite a huge political transformation, there are many challenges in the promotion and protection of human rights. The rule of law is concerned with the principled exercise and accountability of governmentality, but impunity, political crises and destabilization, misuse of power, exclusion, torture in police custody, violence against the women, incidents of rape and murders, etc. are creating challenges in achieving universal human rights and establishment of the rule of law. The government is failing to carry out the recommendation of the United Nations, the policy of inclusion and all international norms of democratic federalism are only on paper.

\section{Conclusion}

The leaders of the political parties succeeded to dismantle the old regime, but they lack the habit of abiding by the constitutional culture. Policy level corruption, that serve the interest of certain groups, has been remained a major challenge in building a rule of law. Corruption control agencies do not file a case and do enough investigation in big scandals of corruption. The tendency of appointing our man, personalization of constitutional bodies and frequent political intervention by the executive authorities further attributed the corruption to the society. The subject committees in the parliament lack a culture of consulting with the stakeholders and experts, and studying the proposed bills seriously. The political leaders, the concerned ministers and their advisors and high level government officials collude with 


\section{Federal Democratic Republic of Nepal}

policy making processes. The process of appointing the judges always leads to controversy and political dominations.

Waggonner's famous work (No Rule of Law, No Democracy, 2016) demonstrates that when corrupt leaders are in power, they will protect their office and fail to implement the rule of law in the country. Due to unwillingness of elected representatives and government officials to reform and adherence to the principle of equality and inclusion, the prospect of democracy seems far away. It needs strong political commitment from the leaders to fight against corruption, reform the law to address the gender based violence, structure of the judicial council, transparent in the appointment process of the judges and office bearers in the constitutional bodies. As mere provisions of the constitution alone cannot redesign a culture that assents impunity, unobtrusive deals and horse-trading as usual, to maintain an independent institution, the constitutional bodies must be keeping out of the political intervention of executive authorities to strengthen the rule of law. Further, innovative norms of politics must be incorporated. The rule of law and reinforcing it in the judicial branch of government is at the sentiment of this redesigning of politics. Nepal must accept the international norms in terms of providing justice and maintain judicial independence, strengthening human rights institutions and building a culture of respect for human rights.

\section{References}

Kosmehl, M. (2020). "Rule of law and fighting corruption." In https://www.bertelsmannstiftung.de/en/our-projects/strategies-for-the-eu-neighbourhood/project-topics/rule-of-lawand-fight-against-corruption/.

Council of Europe. (2016). State of democracy, human rights and the rule of law - A security imperative for europe. https://rm.coe.int/1680646af8.

Freedom Forum. (2020). "Nepal drops in international rankings on central budget transparency". http://freedomforum.org.np/nepal-drops-in-international-rankings-on-centralbudget-transparency/.

Heyhood, A. (2004). Political theory: An introduction. Palgrave Macmillan.

Human Freedom Index. (2019). Human freedom index: A global measurement of personal, civil, and economic freedom. https://www.fraserinstitute.org/sites/default/files/humanfreedom-index-2019-rev.pdf.

Human Rights Watch. (2020). "Nepal events of 2019". https://www.hrw.org/worldreport/2020/country-chapters/nepal.

Inglehart, R. (2009). "Democracy and happiness: What causes what?". In A. K. Dutt \& Benjamin Radcliff (eds.), Happiness, Economics and Politics: Towards a Multi-Disciplinary Approach. 97-126. Edward Elgar Publishing.

International Justice Resource Center. (2015, September). "Nepal adopts secular constitution amid violent protests". https://ijrcenter.org/2015/09/30/nepal-adopts-secularconstitution-amid-violence-and-deadly-protests/. 


\section{Federal Democratic Republic of Nepal}

International Commission of Jurists. (2020). Human rights and the rule of law in a federal Nepal: Recommendations from an ICJ high-level mission. https://www.icj.org/nepal-highlevel-mission-urges-law-and-policy-reform-to-achieve-human-rights-accountability-andstrengthen-justice-sector-institutions-icj-report/.

Informal Sector Service Centre (INSEC). (2020). Nepal human rights year book 2020. https://www.insec.org.np/wp-content/uploads/2020/02/Nepal-Human-Right-Year-Book2020-Eng.pdf.

Myrdal, G. (1970). The challenge of world poverty. Vintage Books.

Panta, Dr D. (2020, July). "Major challenges in anti- corruption drive of nepal and CIAA's roles." Smarika (2020), 130-141.

http://www.ciaa.gov.np/uploads/publicationsAndReports/eZsd1z.pdf

Sodaro, M. J. \& Brown, N. J. (2001). Comparative politics: A global introduction. McgrawHill.

TRIAL International. (2020, May). "Nepal legislation on sexual violence is insufficient and poorly Implemented." https://trialinternational.org/latest-post/nepals-legislation-on-sexualviolence-is-insufficient-and-poorly-implemented/.

The United Nation. (2020, February). "Mapping progress on women's rights in Nepal." https://asiapacific.unwomen.org/en/digital-library/publications/2020/03/mapping-progresson-womens-rights-in-nepal.

The United Nation and the Rule of Law. (2020, October). "What is the rule of law." https://www.un.org/ruleoflaw/what-is-the-rule-of-law/.

USAID (2008, August) Guide to rule of law country analysis: The rule of law strategic framework: A guide for USAID democracy and governance officers. https://pdf.usaid.gov/pdf_docs/Pnadm700.pdf.

World Bank. (2019). Worldwide governance indicators (WGI) project. https://info.worldbank.org/governance/wgi/.

World Justice Project. (2020). The world justice project rule of law index. https://worldjusticeproject.org/sites/default/files/documents/WJP-ROLI-2020-Online_0.pdf. 